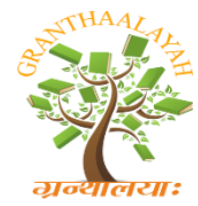

INTERNATIONAL JOURNAL OF RESEARCH GRANTHAALAYAH A knowledge Repository

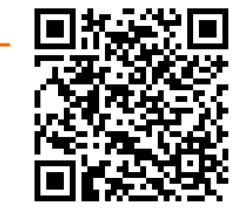

Management

\title{
A STUDY ON INCIPIENT TRENDS: THE REAL ESTATE SECTOR OF AHMEDABAD CITY (GUJARAT)
}

\author{
Dr. Malek Shakilmiya ${ }^{* 1}$, Saiyed Farhana ${ }^{2}$ \\ ${ }^{* 1}$ Principal, F.D. (MUBIN) Institute of Engineering and Technology, Bahiyal, Gandhinagar, \\ Gujarat, India \\ ${ }^{2}$ Assistant Professor, Civil Engineering Department, CHARUSAT Campus, Changa, Gujarat,
} India

DOI: https://doi.org/10.29121/granthaalayah.v5.i1.2017.1905

\begin{abstract}
Risk is an exposure to potential loss or damage. It is a general tendency of people to obtain accurate prediction for the future plans of life, making them feel safe. In the real practice, though all matters are related to special laws however, the interaction and the balance between them is complex. This comes to the fact that the real estate's development is complex and more risky and this may require knowledge and insight in order to professionalize the real estate development process. The complex conditions bring many uncertainties that make it difficult to judge for a perfectly correct prediction. It is therefore, we say that risk is everywhere and unavoidable. The paper highlights the annotations that are identified as the main problems and challenges of risk management in the Indian real estate companies to explore solutions for risk management in India and at last the literature review proceeds toward the highlights of Ahmedabad city of Gujarat state.
\end{abstract}

Keywords: Ahmedabad; Risk Management; Real Estate.

Cite This Article: Dr. Malek Shakilmiya, and Saiyed Farhana. (2017). "A STUDY ON INCIPIENT TRENDS: THE REAL ESTATE SECTOR OF AHMEDABAD CITY (GUJARAT)." International Journal of Research - Granthaalayah, 5(1), 304-315. https://doi.org/10.29121/granthaalayah.v5.i1.2017.1905.

\section{Introduction}

Risk can be defined in different ways depending on the risk management focus, different relations between the objectives and the scope of the research. The risk definition is therefore highly dependent on the choice of applied management focus in any organization. In the real estate sector the management focuses on their specific characteristics such as long cycle, large investment and complicated factors influencing the risks of real estate. Hence the risk management is extremely important in real estate. Risk can be defined as a combination of 
probability of an event occurs and the consequences befalling to achieve the project objectives. Risk is an exposure to potential loss or damage. It is a general tendency of people to obtain accurate prediction for the future plans of life, making them feel safe. In the real practice, though all matters are related to special laws however, the interaction and the balance between them is complex. This comes to the fact that the real estate's development is complex and more risky and this may require knowledge and insight in order to professionalize the real estate development process. The complex conditions bring many uncertainties that make it difficult to judge for a perfectly correct prediction. It is therefore, we say that risk is everywhere and unavoidable. The paper highlights the annotations that are identified as the main problems and challenges of risk management in the Indian real estate companies to explore solutions for risk management in India.

Risk management concept is one that that focuses on the effect of uncertainty of the various risks. The main role of the real estate developer is to minimize these risks to improve the experience of the various stakeholders as well as to generate more profit by managing risk due to different reasons. The real estate sector is growing with the growth of the land rates. There are various companies of different capacity those are creating a cut throat competition in the real estate market. Hence it becomes important to identify the critical risks in the sector.

Table 1: Indian Real Estate Growth History Up to 2000

\begin{tabular}{lll}
\hline Phase & Development & History \\
\hline Before 1970 & Government & DOMINANCY STAGE \\
& dominance & At that time no real estate market, no real estate sales \\
& and exchange was present and the land was supplied \\
& freely as planned by the government. Government \\
& controlled the real estate investment, construction, \\
& exchange and consumption totally.
\end{tabular}

1970-1980 HUDCO \& HDFC HUDCO was established to promote and assist established housing and urban development programs with government agency. HUDCO plays an important role in implementing government initiatives such as the Valmiki Ambedkar Awas Yojna which was launched by Indian governnient during 2001-02 for providing shelter and upgrade the existing shelter for below poverty line people who lives in urban slum areas.

In 1977, Housing development finance Company (HDFC) was established. HDFC was the first company in individual lending which is based on market principles.

1980-1990 Establishment of NBH It also include the involvement of government in directing various agencies like insurance companies, commercial banks (Under priority lending requirements which allowed banks to allocate $1.5 \%$ of their incremental deposits to housing under RBI guidelines), provident funds and mutual funds to invest part of their increment sources on housing. 
1990-2000

Liberalization interest rates

For supporting the Indian real estate sector directly through their newly established housing finance companies and indirectly by investing a proportion their net accretions in socially oriented schemes, two insurance companies LIC and GIC were started.

of This policy was amended in 1994 and providers were free to charge market rates for loans above Rs 25000 . This phase saw a dominance of fixed interest rates, but at the end of the decade variable rate offers started emerging.

In 1995 Indian real estate prices started plummeting between 1995 and 2000. The bubble built on speculations burst and as a result of these prices declined by $30-40$ per cent all over India Due to the growth of if related activity a marginal recovery was observed during 1999-2000.

2000-present Huge growth The real estate market picked up drastically in 2002

Source: Dr. V. Chandrasekhar, "Housing Finance and Housing, A View from India and Beyond", September 2010

With the growth and profitability in housing finance evident, commercial banks stimulated this sector, aggressively increasing their market share. Growth in the housing finance disbursement is shown in figure 1 below:

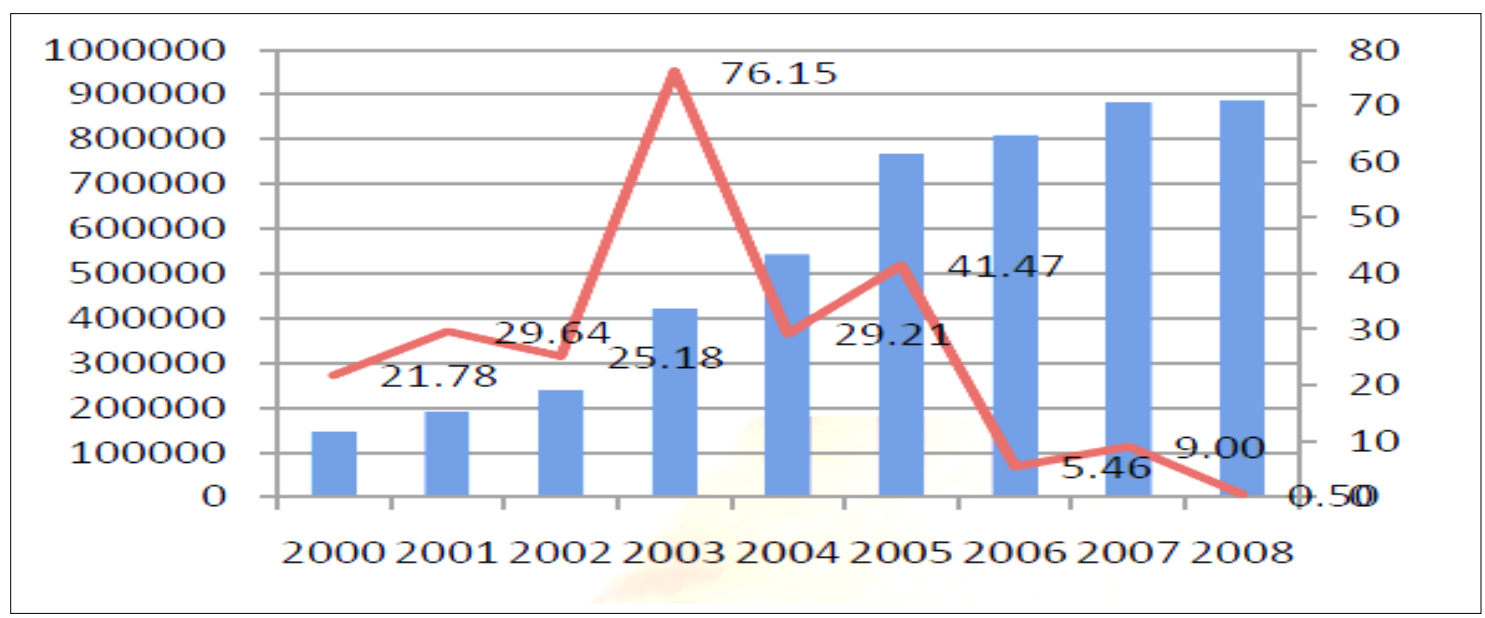

Figure 1: Growth in the Housing Finance

Source: Report: Dr. V. Chandrasekhar, "Housing Finance And Housing, A View From India And Beyond", September 2010

The last decade witnessed a hyperactive boom in the residential property prices. This boom was artificially created where it was backed primarily by the boom in the stock market that was kicked off in 1991. The prices appreciated sharply during 1994 to 1995 whereby it witnessed a phenomenal growth of almost 420 percent from 1990 to 1996. The stock market and real estate markets crashed in quick succession just a little after 1995. This was followed by a prolonged period of about 8 years of little or appreciation in real estate. 
Even though post crisis the real estate sector has taken a major hit, fundamentally things have only improved. Based on the top down approach of the Indian economy the Indian real estate sector is in a multiyear, stable growth phase.

\section{Materials and Methods}

The main objective of this research work focuses on Ahmedabad region of the Gujarat state. As the study is related to this region a glance over the state real estate profile has been provided in the following sections. The research work is concerned with a study of the trends of real estate market in context to Ahmedabad city. Ahmedabad's real estate market is booming because of to the huge growth of its industrial sector and overall high rate of development, both in commercial and residential terms. It is the largest city of Gujarat, and also its commercial capital. The reason for the selection of Ahmedabad for the research work encompasses the following:

1) The growth stimulators for the real estate market in Ahmedabad city are the development of the residential market, malls, office spaces and flyovers changing the cityscape of Ahmedabad. It is observed that the maximum planned activities of residential, commercial and retail development are witnessed in this western micro market of Ahmedabad.

2) Residential real estate of Ahmedabad is dominated by private players and the market is also heavily driven by an active investor base, with most of the participants reaping capital market profits into the real estate markets.

3) Real estate scenario in the city has been immobile in the near term due to the increased home loan rates and slowdown in the equity markets. However, in the long term, we see an appreciation of $9-10 \%$ YoY in property prices over the next 5 years, due to the inherent absorption and launches with the continuous infrastructure developments in the city.

4) In Central Ahmedabad, due to unavailability of land, prices have increased two fold over the last 3 years predominantly in the prime land properties facing C. G. Road. C. G. Road is the most preferred location of Ahmedabad, as it is at the heart of the city and has good connectivity. Commercial and retail sectors have given a paradise look to residence area.

5) Shahibaug which is located in the eastern corridor, is one of the most developed and planned areas of Ahmedabad witnessing an appreciation of 28\% (Mar'11-Feb'12). People from upper and upper middle class prefer to reside in this pocket.

6) Residential areas in North Ahmedabad like New Wadaj and Sabarmati witnessed an appreciation of approximately $22 \%$ (Sept'10-Oct'11) in capital values due to the upcoming residential supply and infrastructure developments being undertaken along Sabarmati. The Ahmedabad Municipal Corporation (AMC) has initiated development of the Sabarmati riverfront. Also a separate company named Sabarmati River Front Development Corporation Limited (SRFDCL) was formed in 1997.

7) Areas like Chandkheda and Motera of North Ahmedabad showed appreciation in land prices due to close proximity to the developing IT and commercial corridor of Gandhinagar.

8) South Ahmedabad replicates Central Ahmedabad as here too, non-availability of land parcels has led to the appreciation of land values. The easy accessibility to AhmedabadBaroda Expressway has given a boost to real estate prices in this region.

9) Retail markets across main streets like Law Garden, C. G. Road and Satellite Road witnessed stagnancy in rental values. 
Table 3: Highlights of Ahmedabad City

\begin{tabular}{lll}
\hline Description & $\mathbf{2 0 1 1}$ & $\mathbf{2 0 0 1}$ \\
\hline Actual Population & $7,208,200$ & $5,816,519$ \\
Male & $3,787,050$ & $3,074,556$ \\
Female & $3,421,550$ & $2,741,963$ \\
Population Growth & $2231 \%$ & $27.25 \%$ \\
Area Square Km. & 8.086 & 8.086 \\
Density/Square Km. & 890 & 727 \\
Sex Ratio (females per & 940 & 892 \\
1000 males) & & $79.50 \%$ \\
Average Literacy Rate & $86.65 \%$ & $87.31 \%$ \\
Male Literacy Rate & $92.44 \%$ & $70.83 \%$ \\
Female Literacy Rate & $80.29 \%$ &
\end{tabular}

The segmentation of the real estate sector is done in five different categories as shown in the following figure 2

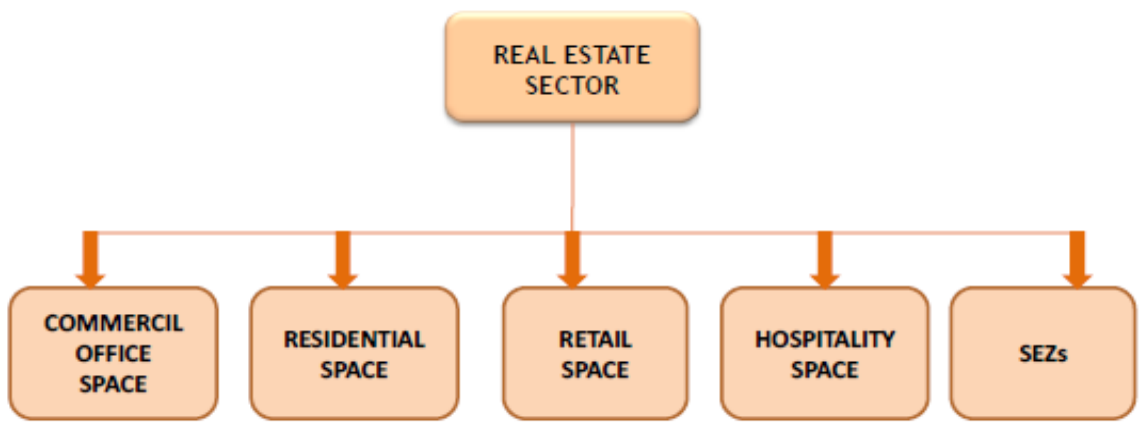

Figure 2: Structure of Real Estate Sector

Source: Mazumdar, Deepak, "Sustainable Urbanization in Real Estate Sector", Central Steering Committee for Housing And Real Estate Market Policy,

Vietnam: 2010

The real estate sector has major 7 aspects which have to be looked towards. These aspects decide the risk factors prevailing in the real estate market.

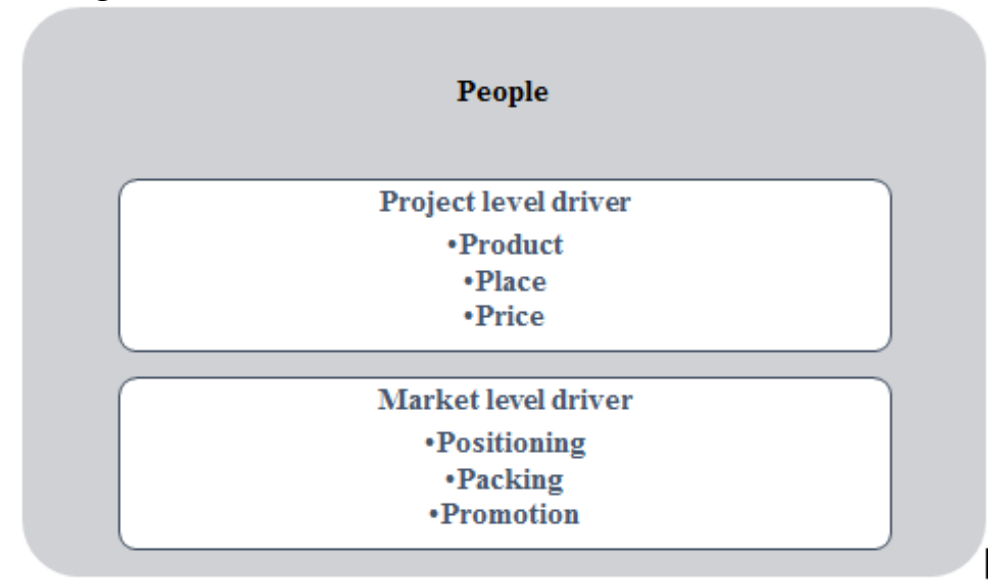


Product relates to real estate investment options that could be of two types - land or property. Property includes commercial, residential, industrial, integrated townships or a mixed-use development.

An entry price is equally important as an exit price in real estate. Investors should follow a bottom-up approach to determine the ideal purchase price of real estate by first determining the expected sale price and other costs that will need to be incurred. If done correctly, this approach will mitigate risks and increase the likelihood and quantum of profits, the eighth $\mathrm{P}$ of real estate. Positioning $i$ s vital in creating an identity in the minds of target consumers of the real estate development being invested in. Positioning in a real estate investment could also refer to the 'relativity' that leads a product to be unique. How a typical development is relatively priced, sized or featured determines how the asset is competitively positioned in the market. Though qualitative in nature, positioning has a direct link to some important qualitative aspects of a property occupancy and yield.

$\underline{\text { Place }}$, or location, is a critical factor to be considered when evaluating a real estate investment. The location and context of a property clearly dictates the level of speculation that the invested asset can be subjected to. In evaluating a particular geography, investors must consider habitation, catchments, infrastructure, expected growth patterns, planned or existing government initiatives, demographic profile, key economic drivers, and so on. Proximity to established nodes of retail or commercial activity can drive the investment interest and value of an asset upwards. Packaging refers to the delivery of a finished product. At a property level, the specifications of the construction, quality of finish, provisions of fit-outs and other facilities like power back-up are a few of the things associated with successful functioning and maintenance of a building. Packaging refers to the timely delivery of good quality products in compliance to the local and national standards for real estate development

Promotion is communication between sellers and buyers of a particular real estate project. Investors must evaluate multiple options to promote the development in which they plan to invest.

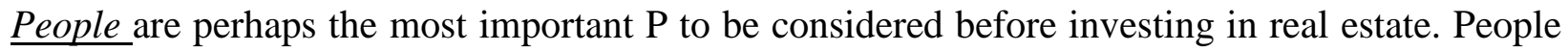
could refer to the target consumers of real estate to be invested in, a developer who has the ability to develop a real estate project as promised or a fund manager with the expertise and market savvy to deliver results

There has been a sheer bull run in the real estate sector in the recent years and it has become more complex and uncertain due to several trends. Risk management has consequently become more important and the reason for this is shown in the following table 2.

Table 2: Indicators of the Need for Risk Management in Real Estate

\begin{tabular}{|c|c|c|c|c|c|}
\hline No & Market & Indicators & \multicolumn{3}{|c|}{ Outcomes of The Condition of Market } \\
\hline 1 & $\begin{array}{l}\text { Complexity } \\
\text { and } \\
\text { uncertainty }\end{array}$ & $\begin{array}{l}\text { Land is scarcer } \\
\text { More finance } \\
\text { is required and } \\
\text { it becomes } \\
\text { harder to } \\
\text { purchase land } \\
\text { More technical }\end{array}$ & $\begin{array}{l}\text { Redevelop } \\
\text { ment is } \\
\text { taking the } \\
\text { place of } \\
\text { new } \\
\text { constructi } \\
\text { on. }\end{array}$ & $\begin{array}{c}\text { Multiple } \\
\text { functions are } \\
\text { combined, for } \\
\text { example } \\
\text { residential and } \\
\text { office buildings } \\
\text { to leisure and }\end{array}$ & $\begin{array}{l}\text { Renewal and expansion } \\
\text { of infrastructure to } \\
\text { guarantee the } \\
\text { accessibility of the } \\
\text { location. }\end{array}$ \\
\hline
\end{tabular}




\begin{tabular}{|c|c|c|c|c|}
\hline & 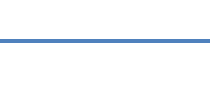 & and logistic & reta & InfoBase Index IBI Factor 3.8 \\
\hline 2 & $\begin{array}{l}\text { Lengthy } \\
\text { duration of } \\
\text { projects }\end{array}$ & $\begin{array}{l}\text { Public parties } \\
\text { collaborate with } \\
\text { private parties } \\
\text { for financial } \\
\text { commitment. }\end{array}$ & $\begin{array}{c}\text { Public private } \\
\text { partnership, Private } \\
\text { private partnerships, } \\
\text { Contractual } \\
\text { arrangements }\end{array}$ & $\begin{array}{l}\text { Risk management is needed to } \\
\text { communicate about project and } \\
\text { support negotiations and } \\
\text { transferring and sharing risk. }\end{array}$ \\
\hline 3 & $\begin{array}{l}\text { National } \\
\text { and } \\
\text { Environme } \\
\quad \text { ntal } \\
\text { regulation }\end{array}$ & $\begin{array}{l}\text { Restrictions are } \\
\text { imposed }\end{array}$ & $\begin{array}{l}\text { Protection of air } \\
\text { quality and promote } \\
\text { sustainability }\end{array}$ & Contracting and tendering \\
\hline
\end{tabular}

The real estate space in Ahmedabad is classified into five distinct zones-Central Ahmedabad, North Ahmedabad, South Ahmedabad, East Ahmedabad and West Ahmedabad.

Table 4: Zones of Central Ahmedabad City with Prize Trends

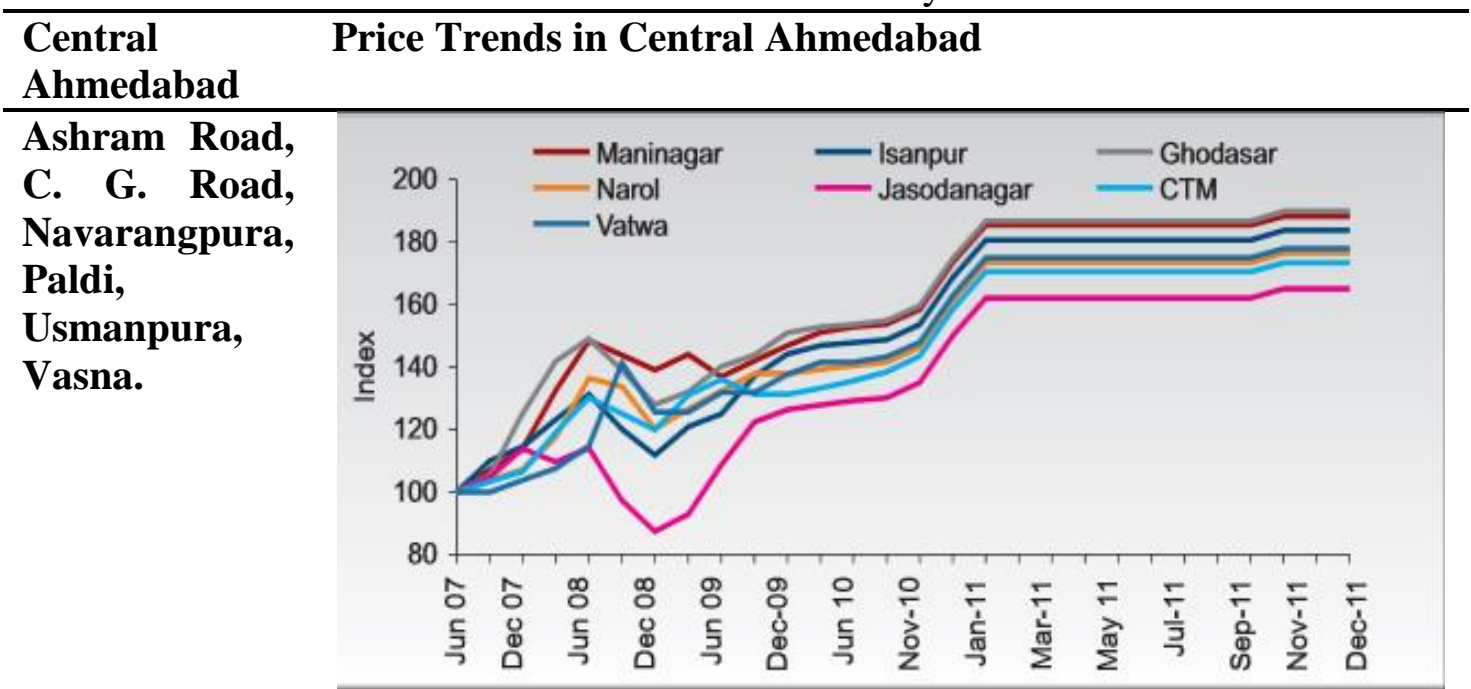

Property rates of ' ready-to-move in' in prime residential markets of Central Ahmedabad

\begin{tabular}{|l|c|c|}
\hline Location & $\begin{array}{c}\text { Average Capital Values } \\
\text { (INR/sft.) }\end{array}$ & $\begin{array}{c}\text { Rentals for 2 BHK } \\
\text { (INR/month) }\end{array}$ \\
\hline Ashram Road & $5,000-6,500$ & 8,500 \\
C. G. Road & $5,000-6,500$ & 10,000 \\
Navrangpura & $4,500-6,000$ & 10,000 \\
Paldi & $4,500-5,500$ & 8,000 \\
Usmanpura & $3,500-4,500$ & 8,500 \\
Vasna & $2,400-3,000$ & 6,500 \\
\hline
\end{tabular}

Source: Ahmedabad Residential Real Estate Overview, March 2012, ICICI Property Services 
Table 5: Zones of North Ahmedabad City With Prize Trends

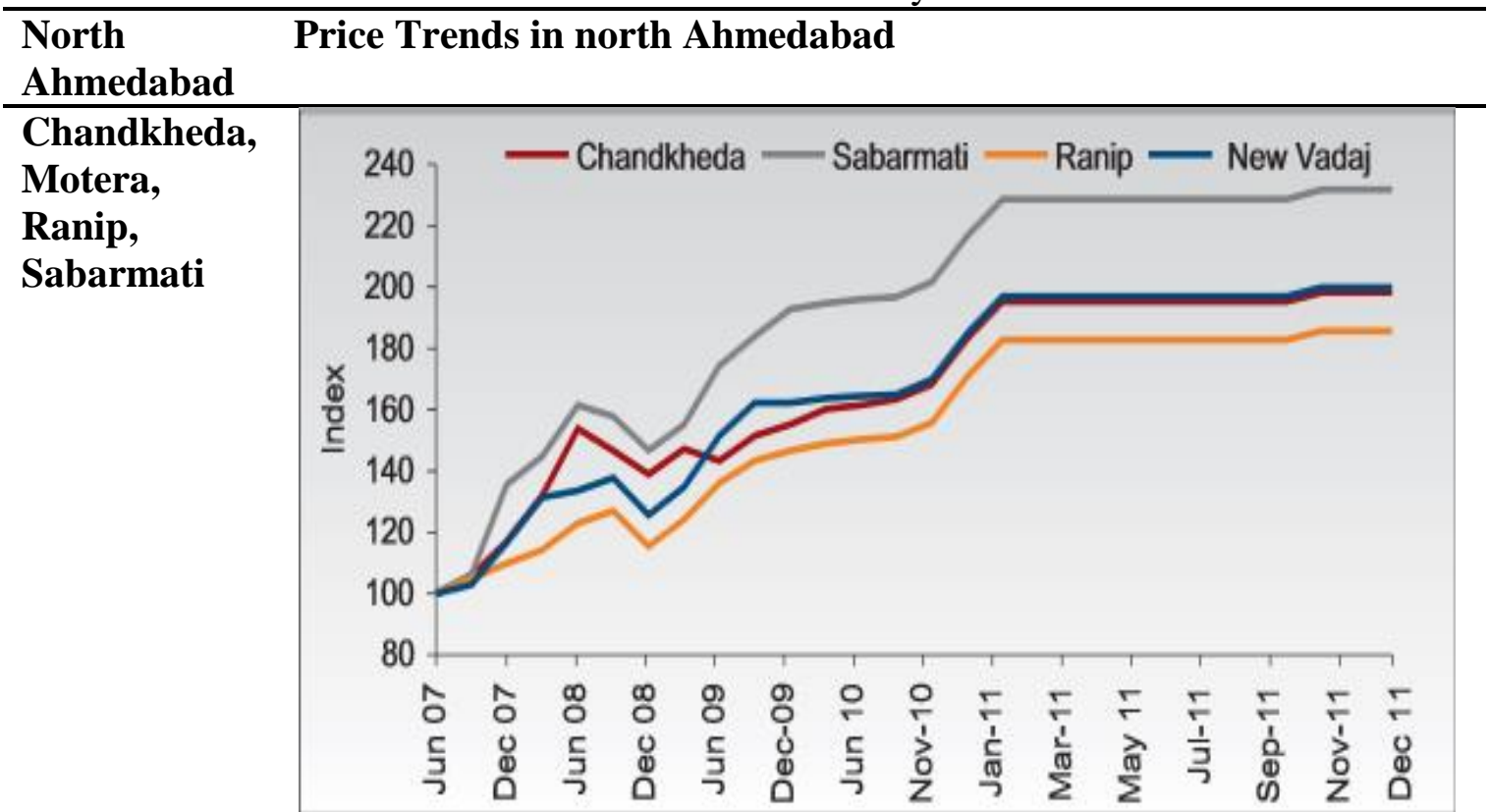

Property rates of ' ready-to-move in' in prime residential markets of North Ahmedabad

\begin{tabular}{|l|c|c|}
\hline \hline Location & $\begin{array}{c}\text { Average Capital Values } \\
\text { (INR/sft.) }\end{array}$ & $\begin{array}{c}\text { Rentals for 2 BHK } \\
\text { (INR/month) }\end{array}$ \\
\hline Chandkheda & $2,400-2,900$ & 6,500 \\
Motera & $2,600-3,000$ & 6,000 \\
New Vadaj & $2,600-2,900$ & 4,500 \\
Ranip & $2,400-2,900$ & 5,500 \\
Sabarmati & $2,400-2,600$ & 6,000 \\
\hline
\end{tabular}

Source: Ahmedabad Residential Real Estate Overview, March 2012, Icici Property Services 
Table 6: Zones of South Ahmedabad City with Prize Trends

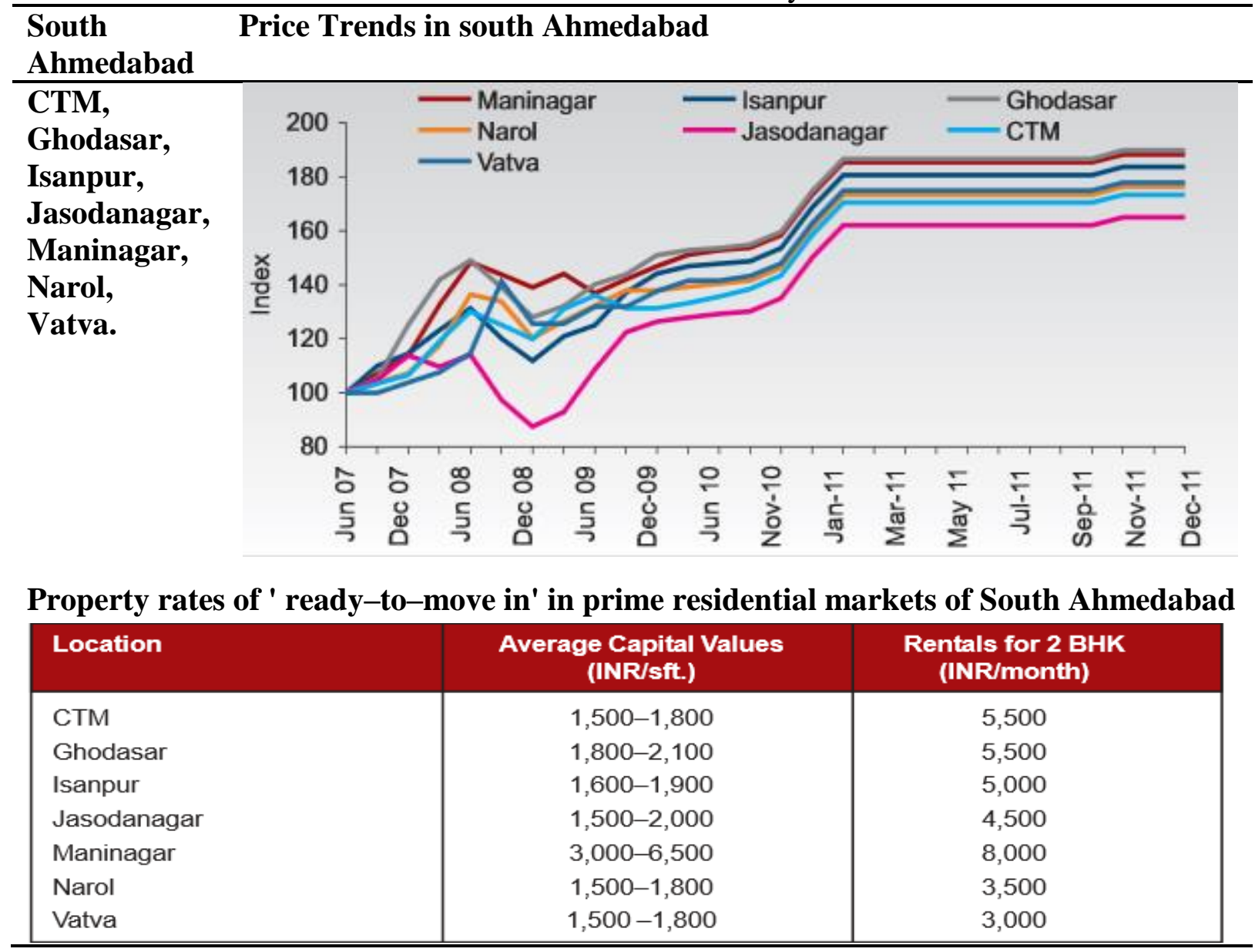

Source: Ahmedabad Residential Real Estate Overview, March 2012, ICICI Property Services

Table 7: Zones of East Ahmedabad City With Prize Trends

East Price Trends in East Ahmedabad

Ahmedabad

Hansol,
Naroda,
Nikol,
Shahibaug

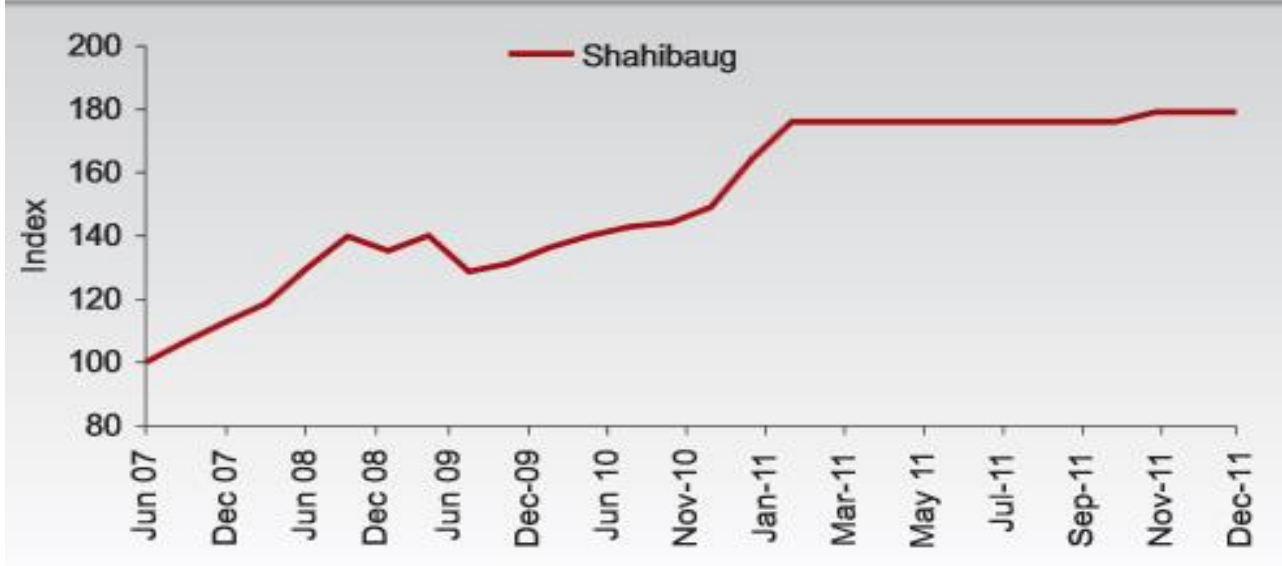

Property rates of ' ready-to-move in' in prime residential markets of East Ahmedabad 


\begin{tabular}{l|c|c|}
\hline Location & $\begin{array}{c}\text { Average Capital Values } \\
\text { (INR/sft.) }\end{array}$ & $\begin{array}{c}\text { Rentals for 2 BHK } \\
\text { (INR/month) }\end{array}$ \\
\hline Hansol & $1,700-2,000$ & 6,000 \\
Naroda & $1,600-2,000$ & 4,000 \\
Nikol & $1,500-1,700$ & 4,000 \\
Odhav & $1,100-1,400$ & 4,000 \\
Shahibaug & $5,000-6,500$ & 13,000 \\
\hline
\end{tabular}

Source: Ahmedabad Residential Real Estate Overview, March 2012, ICICI Property Services

Table 8: Zones of West Ahmedabad City with Prize Trends

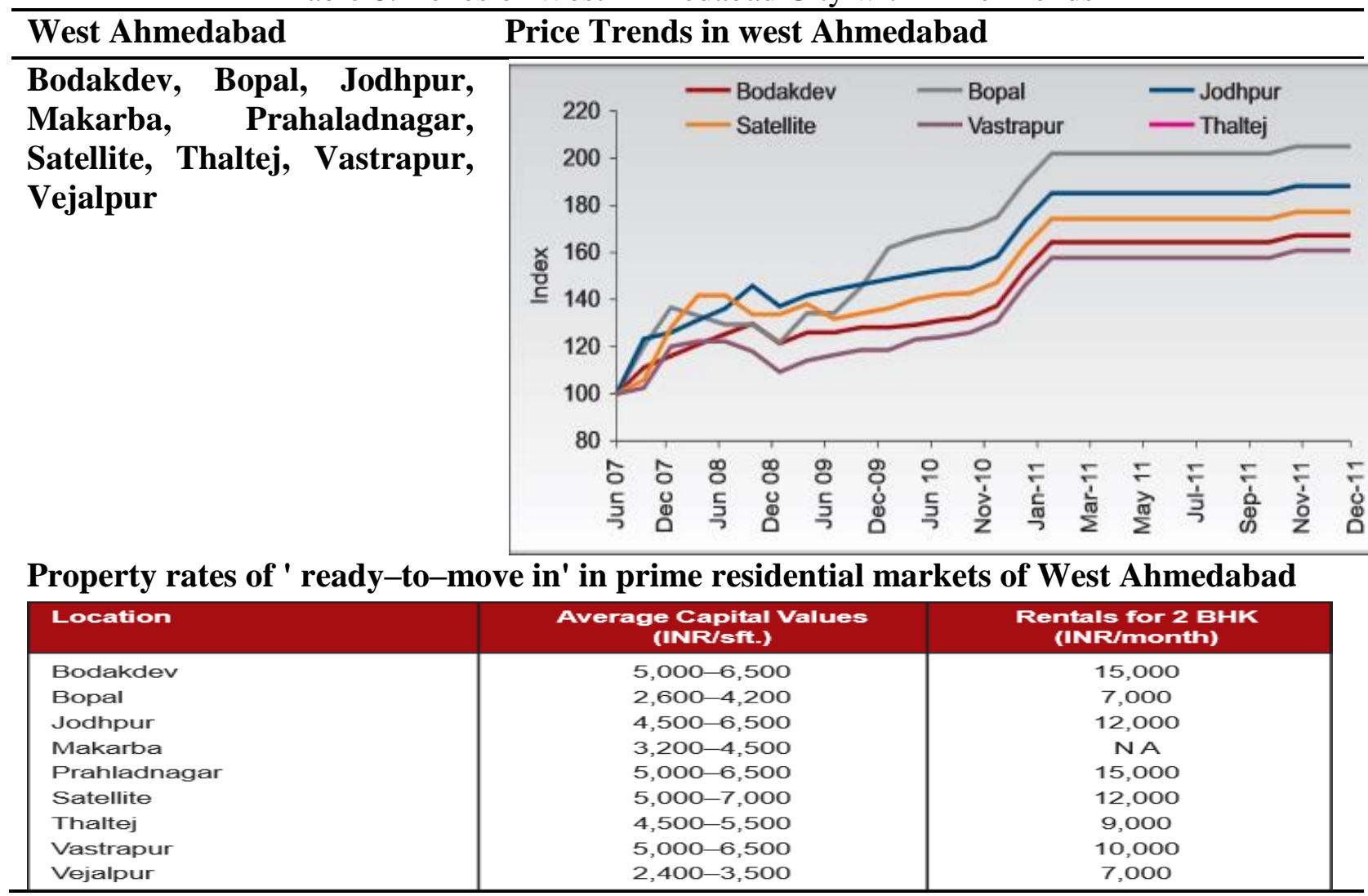

Source: Ahmedabad Residential Real Estate Overview, March 2012, ICICI Property Services

\section{Results and Discussions}

Risk management is not a new concept for the Indian real estate companies. However, it seems that the risks in real estates have been on an increasing pace and there needs an application of the risk management in real estate projects of Ahmedabad real estate sector due to following reasons :

1) The real estate industry encompasses a wide range of sub-sectors, such as the residential office, Industrial, Environmental, infrastructure construction and involves multiple parties which are bounded by their own specific risks. The complexities involved might have raised the barriers for researchers in India to make more insightful studies.

2) Real estate industry does not consist of several large dominant corporations sharing the whole market like the automobile industry or pharmaceutical industry. Those prominent 
corporations always imply their strategies, actions and outlooks widely covered by many public sectors. Unlike the automobiles and pharmaceuticals where correct data can be easily acquired from the market, the real estate industry is kind of fragmented and information limited industry. As individual firms are less likely to share their market information and openly announced the risks they are facing, research on the real estate industry is difficult.

3) The scientific knowledge on the research on the risk management is reduced as the recent prosperous Indian real estate industry made the real estate investors feeling the real estate is a low-tech, high-profit" industry.

\section{Conclusions}

Risk management does not eliminate the risks involved in the real estate sector entirely. It is an approach to manage different risk categories and risk factors in a city like Ahmedabad which in no time will be a metro city. Ahmedabad is a city where there is something for everyone. In fact it is a city which offers $2 \mathrm{BKH}$ flats for 25 lacs within city premises. Increased migration of people and urbanization calls for risk management. The real estate sector in India has been becoming more organised, this is because of the entry of international real estate players, foreign investors and Indian corporate houses. So the real estate sector is facing a challenge to meet the rising demands for the world class infrastructure in cities, housing across different income level and create sustainable cities for future generation.

\section{References}

[1] "Indian Real Estate Industry: Sector view", Market Report. Mumbai: Idea's 1st Research, 2010.

[2] "Indian Real Estate Overview, Research Report", Mumbai: Crisil Research, 2010.

[3] "Inflation India 2012", Inflation.eu - Worldwide Inflation Data, Triami Media BV, 15 December $2012,111-124$.

[4] Akintoye, A S and MacLeod, M J., "Risk analysis and management in construction", International Journal of Project Management, Volume 15, Issue No.1, 1997, 31-38.

[5] Architectural Management, Volume 314, Issue No. 4, 2007, 346-362.

[6] Ben Bulloch, John Sullivan, "Information - The Key to the Real Estate Development Process", Volume 8, Issue No. 1, Article 12, July 2010, 78-87.

[7] Chandrashekhar V. and Katyayini Krishnamoorthy, "Housing Finance and Housing", A view from India and beyond", September 2010, 2-23.

[8] Changwen Ke, Zongjun Wang and Guo Cheng, "The financing and abandonment options in Chinese real estate development projects." Journal of Corporate Real Estate, Volume 19, Issue No. 2, 2007.

[9] Dale Domian, Rob Wolf ,Hsiao-Fen Yang, "An assessment of the risk and return of residential real estate", Journal on Managerial Finance, DOI 10.1108/MF-07-2013-0195, Volume 41, Issue No.6, 4 January 2015, $591-599$.

[10] David J. Hartzell, Robert H. Pittman, David H. Downs, "An Updated Look at the Size of U.S. Real Estate Market Portfolio", April 1992.

[11] Dixon Tim, "The impact of information and communications technology on commercial real estate in the new economy." Journal of' Property Investment \& Finance, Volume 23, Issue No. 6 , 2005, 480-493.

[12] Dr. Ashok Bansal, Mr. Rajeev Sirohi, Manish Jha, "A Review on Indian Real Estate: Trends, Challenges and Prospectus”, KKIMRC IJRHRM, Volume1, Issue No.1, Sep-Nov 2011, 39-54. 
[13] G. Eason, B. Noble, and I.N. Sneddon, "On certain integrals of Lipschitz-Hankel type involving products of Bessel functions," Phil. Trans. Roy. Soc. London, vol. A247, pp. 529-551, April 1955. (references)

[14] Gerald F. Blundell, Simon Fairchild, Robin N. Goodchild, "Managing Portfolio Risk in Real Estate", Journal of Property Research, ISSN 0959-9916 print/ISSN 1466-4453, DOI: 10.1080/09599910500456759 „June-September 2005, Volume 22, Issue No. 2-3, 115-136,

[15] Gill Amarjit, Nahuni Biger, Neil Mathur, and Rajendra Tibrewala, "Understanding and Mitigating Direct Investment Risk in the Indian Real Estate Market", Business and Economics Journal, December 2010, 1-10.

[16] Hao Yukai, Wang Wei, "Risk Identification and Risk Evaluation on Real Estate Development" , Proceedings of the 7th International Conference on Innovation \& Management, 2023-2027.

[17] Harihan, Ganesh, Shashaiik, Narayan, Shankar Devi, "Reaping the Returns", India Capital Market Report, Mumbai: Jones Lang LaSalle, 2011.

[18] Himadri Mayank, Hariharan Ganesan, Abhishek Kiran Gupta, "Indian Real Estate- Charting a Global Course", India Capital Market Report, Mumbai: Jones Lang LaSalle, 2011.

[19] India Real Estate Sector Report, Economic research, Kuwait: Global Investment House, 2008.

[20] India, "The Working and Operations of Reserve Bank of India", The Annual Report on The Working of The Reserve Bank of India, Government of India, 2012, 75-82.

[21] India. Ministry of Environment and Forest. Draft Report on Formulation of Revised Environmental Clearance Process - Phased Implementation Plan, New Delhi: Government of India, 2010.

[22] Iroham, Chukwuemeka Osmond, Oloyede, Samuel Adesiyan , Ajibola, Mayowa Olusola , Durodola, Olufemi Daniel, "Towards an Effective Real Estate Agency Education: A Stride to Efficiency in Nigeria”, WCES 2014, Procedia - Social and Behavioral Sciences 191, 2015 ,26872692, DOI: 10.1016/j.sbspro.2015.04.360,

[23] Jagannath Mallick, "Trends and Patterns of Private Investment in India", Working Paper, Bangalore: The Institute for Social and Economic Change, 2009, 1-16.

[24] Jayanth R. Varma, "Risk Management Lessons from the Global Financial Crisis for Derivative Exchanges", Working Paper No.2009-02-06, Indian Institute of Management (IIM) Ahemedabad, February 2009.

[25] Journal of Project Management, Volume 22,Issue No.1, 2004,51-61.

[26] Kryvobokov Marko, "What location attributes are the most important for market value? Extraction of attributes from regression models", Property Management, Volume 24, Issue No. 3, 2006, 257-286.

[27] Mazumdar, Deepak, "Sustainable Urbanization in Real Estate Sector", Central Steering Committee for Housing and Real Estate Market Policy, Vietnam, 2010.

[28] Ronald W. Kaiser, Jim Clayton, "Assessing and Managing Risk in Institutional Real Estate Investing", Journal of Real Estate Portfolio Management, Volume 14, Issue No. 4, 2008, 287 305.

[29] Shobhit Agrawal, "Reaping the Returns- Private Equity Real Estate Exits in India", Jones lanf lasalle india capital market report, 2011.

[30] Zhang, Xing Quan, "Housing Reform and The new Governance of Housing in Urban China, "International Journal of Public Sector Management, Volume 13, Issue No. 6, 2000, 519-525.

[31] Zhao, Xuehong, "Study Study on the Real Estate Investment in Cities - Sample as JiNan Quanjing Garden”, Master thesis, Shandong University, 2006.

*Corresponding author.

E-mail address: shakil250715@yahoo.co.in 